\title{
Anticipation resulting in elimination of the myotonic dystrophy gene: a follow up study of one extended family
}

\author{
C E M de Die-Smulders, C J Höweler, J F Mirandolle, H G Brunner, V Hovers, \\ H Brüggenwirth, H J M Smeets, J P M Geraedts
}

\begin{abstract}
We have re-examined an extended myotonic dystrophy (DM) family, previously described in 1955, in order to study the long term effects of anticipation in DM and in particular the implications for families affected by this disease. This follow up study provides data on 35 gene carriers and 46 asymptomatic at risk family members in five generations. Clinical anticipation, defined as the cascade of mild, adult, childhood, or congenital disease in subsequent generations, appeared to be a relentless process, occurring in all affected branches of the family. The cascade was found to proceed asynchronously in the different branches, mainly because of an unequal number of generations with mild disease. The transition from the mild to the adult type was associated with transmission through a male parent. Stable transmission of the asymptomatic/mild phenotype showed a female transmission bias.
\end{abstract}

We further examined the extent and causes of gene loss in this pedigree. Gene loss in the patient group was complete, owing to infertility of the male patients with adult onset disease and the fact that mentally retarded patients did not procreate. Out of the $\mathbf{4 6}$ at risk subjects in the two youngest generations, only one was found to have a full mutation. This is the only subject who may transmit the gene to the sixth generation. No protomutation carriers were found in the fourth and fifth generations. Therefore it is highly probable that the DM gene will be eliminated from this pedigree within one generation. The high population frequency of $D M$ can at present not be explained by the contribution of asymptomatic cases in the younger generations of known families, but is probably caused by the events in the ancestral generations.

(f Med Genet 1994;31:595-601)

Myotonic dystrophy (DM) is an autosomal dominant disorder with myotonia and muscular weakness as diagnostic features. Apart from the muscular manifestations, it is characterised by multiple systemic effects including cataract, mental retardation, cardiac involvement, and testicular atrophy. Extreme variability is one of the hallmarks of the disease; clinical studies have led to the recognition of four disease types on the basis of age at onset and core symptoms: late onset (mild) type, adult onset (classical) type, childhood, and congenital type..$^{1-3}$

Anticipation, increasing severity and earlier age at onset in successive generations, has been observed in DM since the beginning of this century, but remained unexplained and controversial until recently. ${ }^{4-7}$ With the discovery of an unstable CTG trinucleotide repeat in the $3^{\prime}$ untranslated region of a protein kinase gene on chromosome $19 \mathrm{q}$, a biological explanation for this phenomenon has emerged. ${ }^{8-14}$ The repeat length correlates with the severity of clinical symptoms and increases with transmission to subsequent generations. ${ }^{371516}$ However, most of the dynamics of the unstable CTG trinucleotide repeat are not yet fully understood.

The exact implications of anticipation for DM families are still unclear. As a rule the anticipation cascade proceeds and the phenotype changes from mild type to adult type to childhood/congenital type in subsequent generations. However, it is not known which events precede the cascade, which factors trigger the start of the cascade, and what happens after the childhood/congenital onset generation. Fleischer $^{4}$ argued that the disease would become extinct in families because of gene loss in severely affected patients owing to celibacy, childless marriages, mental retardation, and high infant mortality. Follow up studies to determine whether the disease indeed disappears from a given family have not been performed. We had the opportunity to re-examine a large DM family, the first three generations of which were described by de Jong ${ }^{17}$ in 1955, and so we could gain data on five generations. The aim was to study the consequences of anticipation over more generations than can be studied in transverse studies. The inter- and intragenerational phenotypic variation was studied by combining clinical and DNA data. The reproductive fitness of male and female patients was compared. To examine whether progressive severity leads to the extinction of the disease from a given pedigree, descendants of the third and fourth symptomatic generations were
Dr de Die-Smulders

Accepted for publication 18 April 1994 
studied, and the extent and causes of gene loss in the youngest generations were evaluated.

\section{Methods}

FAMILY

In 1955 de Jong ${ }^{17}$ described an extended DM family with three symptomatic generations (pedigree $\mathrm{G}$ ). He gave detailed information on 50 family members, 16 of whom were designated as affected. Neurological examination and slit lamp examination by an ophthalmologist were used as diagnostic methods. Electromyography was not available then. We carefully reviewed his data and only subjects showing definite signs of DM were classified as affected. We added data on the descendants of III.12, who were examined by de Jong in 1958 (figure). II.2 and her descendants are not included in this follow up study, because she was not examined by de Jong. III.8, III.9, and III.10 and their children were found to be normal in 1955 . They live abroad and were excluded from the present study. The living members of generations IV and V were re-examined and so we were able to obtain data on five generations.

This follow up study was started with the patients and at risk family members already known to the Departments of Clinical Genetics and Neurology of the University Hospital Maastricht and the Department of Neurology of the De Wever Hospital in Heerlen, the Netherlands. They were asked to approach their relatives. Most family members were visited and examined in their own homes, which turned out to have a significant advantage in terms of cooperation in the study.

The total study comprises data on $\mathbf{8 1}$ family members: initially there were 35 symptomatic patients or obligate gene carriers (including de Jong's patients) and 46 at risk subjects. The at risk group comprised asymptomatic first degree relatives of DM patients. Second and third degree relatives were defined as at risk if the disease status of the intermediate family member(s) was unknown. One at risk subject (V.20) was included in the group of gene carriers after DNA examination showed that she had inherited the expanded CTG repeat from her affected father. Eighteen out of the $\mathbf{3 6}$ gene carriers were no longer alive at the time of the study.

\section{EXAMINATIONS}

Careful histories from the patients or their family members or both were obtained to document the age of onset and current clinica symptoms. When available, clinical records were reviewed. Muscular weakness or myotonia or both, myotonic cataract, neonatal symptoms, or mental retardation defined the onset of disease. Neurological examination was performed using a standardised form. Ophthalmological assessments were carried out using a portable slit lamp. EMG examination was only performed when the examination took place in hospital.

\section{CLINICAL CLASSIFICATION}

To compare the disease types within and between generations four clinical categories were used, adapted from the classification of Harley et $a^{3}$ : mild, adult, childhood, and congenital types. We added a category of additional later symptoms, because several of the present patients have had symptomatic DM for over 40 years (table 1). Conclusions regarding the disease type were made on the basis of the results of our recent examination in combination with the data from medical records and de Jong's descriptions.

\section{DNA ANALYSIS}

Chromosomal DNA was isolated from peripheral blood cells from 16 patients and 39 at risk subjects. Molecular analyses were

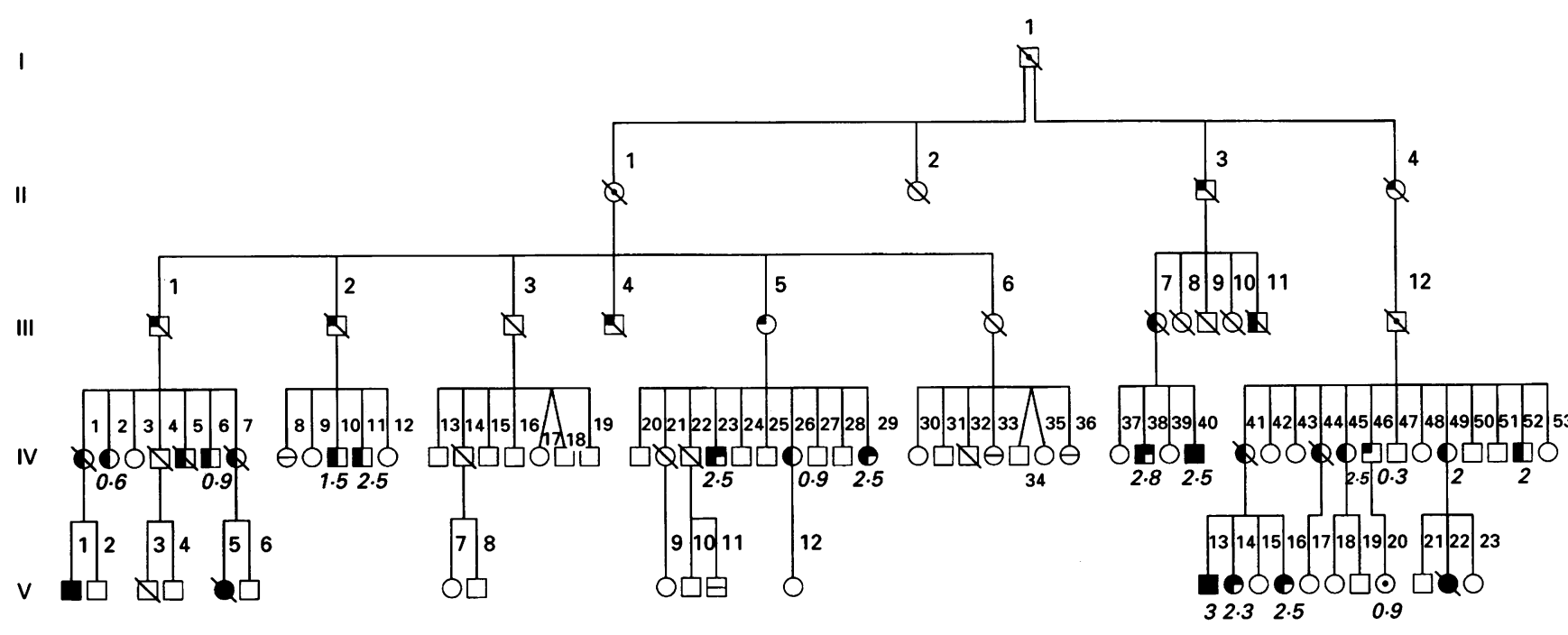

$\square$ Normal on clinical/DNA examination $\square \odot$ Asymptomatic gene carrier $\circlearrowright \odot$ Mild type

DAdult type $\square$ Childhood type

Congenital type $\boxminus \ominus$ Not examined 
Table 1 Disease types in DM related to age at onset and core symptoms

\begin{tabular}{llll}
\hline $\begin{array}{l}\text { Disease } \\
\text { type }\end{array}$ & $\begin{array}{l}\text { Age at } \\
\text { onset }(y)\end{array}$ & Initial symptoms & Additional later symptoms \\
\hline Mild & $>50$ & $\begin{array}{l}\text { Cataract or iridescent } \\
\text { lens opacities }\end{array}$ & $\begin{array}{l}\text { Myotonia } \\
\text { Mild weakness }\end{array}$ \\
Adult & $10-50$ & $\begin{array}{l}\text { Myotonia } \\
\text { Muscular weakness } \\
\text { Testicular atrophy }\end{array}$ & $\begin{array}{l}\text { Progressive weakness } \\
\text { Inertia, hypersomnia } \\
\text { Cataract }\end{array}$ \\
Childhood & $1-10$ & $\begin{array}{l}\text { Neonatal symptoms absent } \\
\text { Speech/learning difficulties } \\
\text { or mental retardation }\end{array}$ & $\begin{array}{l}\text { Muscular weakness } \\
\text { Varying degree of mental } \\
\text { retardation } \\
\text { No myotonia before school age } \\
\text { (abdominal symptoms) }\end{array}$ \\
Congenital & $<1$ & $\begin{array}{l}\text { Reduced fetal movements } \\
\text { Polyhydramnios } \\
\text { Neonatal problems: hypotonia, } \\
\text { facial diplegia, } \\
\text { joint immobility, } \\
\text { respiratory insufficiency }\end{array}$ & $\begin{array}{l}\text { Initial improvement of weakness } \\
\text { Psychomotor retardation }\end{array}$ \\
No myotonia before school age \\
(abdominal symptoms)
\end{tabular}

performed according to methods described previously. ${ }^{912141819}$ Southern blot analysis was performed using restriction enzyme HindIII and probe pGB2.6 respectively. In those samples where smears were detected, the middle of the smear was sized. Expansions $<0.35 \mathrm{~kb}$ were also sized on polyacrylamide gels, after PCR amplification using primers flanking the CTG repeat. ${ }^{14}$ All molecular results were expressed in terms of kilobases of additional DNA.

\section{Results}

PEDIGREE

The abbreviated pedigree is depicted in the figure; only gene carriers and their descendents and at risk persons are shown. The disease types are given in the pedigree. Generations II, III, and most members of generation IV were studied in 1955 or 1958 . All subjects of generations I, II, and III are dead. The common ancestor of generation II (I.1) was born in 1833 and died at the age of 84 . According to his children he never had visual or muscular complaints. Thus he was probably an asymptomatic gene carrier. In generation II, two subjects have had cataract operations (II.3, II.4). When examined aged 80 and 76 years respectively, they showed no muscular signs. Subject II.1 died at the age of 26, a few days after the birth of her sixth child. In generation III, four patients had mild disease and two had the adult type, transmitted by their father. III.12 had no muscular signs when examined at the age of 54 . Slit lamp examination, however, was not performed. Patients still alive in generation IV are now aged 38 to 69 years. The most frequent type in generation IV is adult onset disease, with a few exceptions: one male is congenitally affected (IV.40) and three patients have the childhood form (IV.23, IV.29, IV.38); in all four cases the disease was transmitted by their affected mother. These four patients with early onset disease are aged $46,64,47$, and 56 years respectively. They are still able to walk with walking aids, despite having had symptoms for more than 40 years. They are moderately mentally retarded and not able to live independently. One gene carrier in generation I.V (IV.46) has minor symptoms. This 52 year old man was found to be normal on clinical and slit lamp examination. However, DNA analysis showed that he carried the DM mutation, containing a $0.3 \mathrm{~kb}$ expansion. Electromyography, that happened to be performed some years previously, showed myotonic discharges. Based on these results he was classified in the mild group. This is in sharp contrast to his five affected sibs, who have (early) adult onset disease with expansions of 2 to $2.5 \mathrm{~kb}$. The age of the living patients in generation $\mathrm{V}$ is between 31 and 41 years. In this generation, four patients had congenital disease, two of whom died in the neonatal period, and two patients have childhood onset disease. The 16 year old daughter of IV.46 (V.20) was asymptomatic on clinical and slit lamp examination, but DNA studies showed that she has inherited the mutated paternal chromosome, containing an expansion of $0.9 \mathrm{~kb}$. She is of normal intelligence and is attending secondary school; we presume she will develop (late) adult onset disease.

\section{INTERGENERATIONAL DIFFERENCES IN PHENOTYPE}

In the different branches a variable number of generations with mild disease was observed. The mild type was most frequently present in two generations and the transition from the mild to the classical type occurred from generation III to IV; $72 \%$ of the gene carriers in generation IV had the adult onset type. In one branch this transition occurred one generation earlier (offspring of II.3). In another case the transition was one generation later (transmission line II.4-III.12-IV.46-V.20). This unequal number of generations with mild disease in the different branches resulted in the occurrence of the adult type in three different generations: III, IV, V (assuming V.20 will have adult type disease). Also as a result of this asynchronous anticipation a large intragenerational variation in disease types was found, becoming most obvious in generation IV, in which patients with four different disease types are present.

Disease types were compared in 32 parentchild pairs in generations II to V: 16 motherchild pairs and 16 father-child pairs. For this analysis we combined the asymptomatic and mild patients and designated them as having the mild type, because inclusion in one group or the other strongly depends on the age at which a 
subject was examined. We also combined the childhood and congenital onset groups, because the prognosis of these patients is essentially determined by their mental retardation. Parental disease type was mild/asymptomatic in 24 . Six children of a parent with mild disease also had mild disease; in five of these six stable transmissions of the mild type the mother was the transmitting parent. Sixteen children of a parent with mild disease had the adult type. In 15 of these 16 mild to adult transitions the gene was transmitted by a male gene carrier. In two cases maternal transmission of the mild type results in direct transition to childhood disease in her offspring (III.5-IV.23 and III.5-IV.29). III. 5 was 50 years old when examined by de Jong in 1955 . At that time her only symptoms were a slightly myopathic face and iridescent lens opacities on slit lamp examination. Unfortunately DNA studies could not be performed in this woman. There were eight parent-child pairs in which the parent had adult onset disease. The parents were all female. These women had no offspring with adult onset disease; all their children were normal or had childhood/congenital disease. None of the males with adult onset disease had offspring.

CORRELATION OF DISEASE TYPE AND REPEAT SIZE DNA data were obtained from $17 \mathrm{DM}$ gene carriers, with the following disease types: mild (1), adult (8), childhood (5), congenital (2), and asymptomatic (1). The repeat sizes are given in the pedigree (figure). Congenitally and childhood affected patients showed the largest bands. Patients with repeat sizes of approximately $2.5 \mathrm{~kb}$ were found in the adult group and in the childhood and congenital onset group. Vertical transmission of the CTG repeat could only be studied in one father-daughter pair (IV.46 and V.20); repeat lengths were 0.3 and $0.9 \mathrm{~kb}$ respectively.

\section{AT RISK GROUP}

Forty six asymptomatic at risk persons were examined. Their status is given in table 2 .

Table 2 Residual risk of being a gene carrier in at risk group ( $n=46)$

\begin{tabular}{llllll}
\hline & Risk & & & & \\
\cline { 2 - 6 } & Excluded & Affected & $50 \%$ & $25 \%$ & $8 \%$ \\
\hline No & 38 & 1 & 1 & 3 & 3 \\
\hline
\end{tabular}

Thirty eight of these 46 subjects were proven not to be gene carriers; they showed no clinical abnormalities and DNA analysis showed that they had inherited the normal allele from their affected (grand)parent. One at risk subject (V.20) was found to be carrying the DM gene with an expansion of $0.9 \mathrm{~kb}$. Four subjects (IV.8, IV.33, IV.36, V.11) refused to cooperate in the study. In three subjects (V.2, V.15, V.19) DNA analysis could not be performed. As they were normal on clinical examination, including slit lamp examination and electromyography, their residual risk was $8 \% .^{20}$

\section{CAUSES OF GENE LOSS}

We found three causes of gene loss: infertility, infant mortality, and the fact that mentally retarded patients did not procreate. The fertility of the patients, as defined by disease type and by sex of transmitting parent, is given in table 3. A remarkable difference between the sexes was observed in the adult onset group. Only one of the nine women with adult onset DM was childless, while the other eight women had a total of 19 children. These females are now all middle aged and have completed their families. In contrast none of the six adult onset males has produced children; they are between 39 and 63 years of age and are all single, which makes it unlikely that they will produce offspring in the future. Childlessness of the male patients with adult onset disease accounted for $35 \%$ of the gene loss in generations IV and V. Infertility of the female patients with adult onset disease accounted for only $6 \%$ of gene loss. Patients with congenital or childhood disease are all mentally retarded, unable to live independently, and childless. They are beyond the age of 30 and are also unlikely to have offspring in the future. Childlessness owing to mental retardation was responsible for $47 \%$ of the total gene loss. Infant mortality in this family involved two children with congenital $\mathrm{DM}$ in generation $\mathrm{V}$ and accounted for $12 \%$ of the gene loss.

The effects of the different causes of gene loss are also reflected in the number of patients in each generation, as given in table 4 . The largest number of patients is found in the third symptomatic generation (generation IV). The first decline in the number of gene carriers, after generation IV, is mainly owing to infertility of the male patients with adult type DM. The second expected decline, after generation $\mathrm{V}$, is because of the childlessness of childhood/con-

Table 3 Number of children of DM gene carriers aged over 20 years ( $n=35$ ) by disease type and sex of the transmitting parent

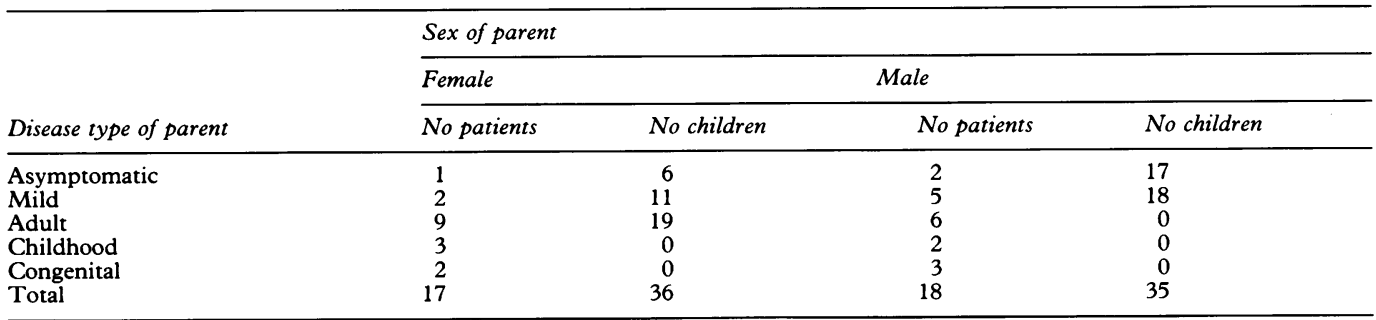


Table 4 Number of gene carriers by generation

\begin{tabular}{lllllll}
\hline & \multicolumn{3}{l}{ Generation } & & & \\
\cline { 2 - 7 } & $I$ & $I I$ & $I I I$ & $I V$ & $V$ & $V I$ \\
\hline No of gene carriers & 1 & 3 & 7 & 18 & 7 & $\begin{array}{l}1 \text { or } 2 \\
\text { expected }\end{array}$ \\
\hline
\end{tabular}

genitally affected patients of both sexes. Only one female gene carrier in generation V (V.20) will be able to transmit the gene to generation VI. If the anticipation proceeds in her descendants as in the rest of the family, her children may have childhood or congenital onset disease. Therefore the gene may be expected to be eliminated from this family within one or two generations.

\section{Discussion}

We re-examined an extended myotonic dystrophy family previously documented in 1955, and analysed the effects of anticipation in a larger number of generations than can be studied in transverse studies. We collected clinical information on five generations and DNA data on the fourth and fifth generations, in order to examine the probability of transmission of DM to the sixth generation.

Anticipation can be defined at two levels. At the clinical level it is a cascade of mild, adult, and childhood or congenital disease types in subsequent generations. At the molecular level it can be defined as a stepwise increase of the CTG repeat number. A broad correlation between clinical anticipation and DNA expansion has been shown by several authors. ${ }^{321-23}$

In this extended family clinical anticipation occurred in all 21 vertical transmission lines descending from the common ancestor I.1. No protomutations ( 50 to 80 repeats) were found in the asymptomatic members of the fourth and fifth generations. Thus the presumed protomutation of the common ancestor must have been unstable to such a degree that anticipation was a relentless process in all affected branches of the family.

However, the anticipation cascade developed asynchronously in the different branches, mainly depending on the number of generations with mild disease. The start of the cascade, that is, the transition from mild to adult type disease was most frequently seen after two generations with mild disease. An earlier start, after only one generation with mild disease, was seen in one branch (descendants of II.3), while in another vertical transmission line (descendants of II.4) anticipation was postponed, because three generations with asymptomatic/ mild disease preceded the cascade.

The sex of the transmitting parent appeared to be the main influence on the transition from mild to adult type. Fifteen out of the 16 transitions from mild to adult onset disease resulted from male transmission. In contrast, in five out of six stable transmissions of the mild type a female was the transmitting parent. An exception was a mildly affected woman (III.5) who had two children with childhood onset disease as well as a daughter with adult onset disease. This was the only direct transition from the mild to the childhood type observed in this family. Another exception was the asymptomatic male III.12 who had one son with mild disease as well as five children with adult onset disease. It can be concluded from these observations that gender is an important, but not the only, factor determining the start of the cascade.

In eight transmission lines the classical three step anticipation cascade was observed with mild, adult, and childhood/congenital type in subsequent generations. A two step cascade, present 13 times, occurred for two reasons. Firstly because of the absence of the last step of the cascade (childhood/congenital type). This was the case in all six male patients with adult onset disease and was because of infertility. There were also five females with adult onset disease who had no offspring with childhood/ congenital onset disease. Three of these women had only normal children and two were single (so far). The second reason for a two step cascade was the above mentioned direct conversion of the mild type into the childhood type.

Our observations on anticipation in a five generation DM family are unique, as longitudinal studies of DM families have not been previously reported. Transverse studies have shown anticipation in the clinical sense or at the DNA level or both in the great majority of parent-child pairs studied. 4621 24-26 $^{\text {Asynchro- }}$ nous anticipation occurred in some of the reported pedigrees as ages of onset of patients in the same generation differed considerably. ${ }^{612527}$ However, the course of the cascade and the ultimate effects of continuing anticipation can be studied more completely in longitudinal studies. In the transverse study of Barceló et $a l,{ }^{24}$ the stable transmission of a protomutation ( \pm 60 repeats) through four successive generations was described, where symptomatic DM occurred in other branches of their family. The authors concluded that a protomutation may be passed down relatively stably through many generations and may contribute to the genetic reservoir of DM in the population. ${ }^{24}$ Our study does not support this supposition. We found clinical anticipation in all affected branches of the family. We therefore presume that once anticipation starts in offspring of a given gene carrier, anticipation will occur in all affected branches descending from this gene carrier within a limited number of generations. As our results are based on only one extended family, more follow up studies are needed to confirm these findings.

The gender differences we found with regard to transmission are in agreement with the results of others. ${ }^{2324} 28$ Our clinical observation that the transition from mild to adult type is strongly associated with male transmission confirms previous data from molecular and genealogical studies that the probability of initial expansion of the CTG repeat is greater for paternally than for maternally transmitted small mutations. ${ }^{232428}$ As an exception we twice observed a direct transition from the mild to the childhood type DM after maternal transmission. Similar direct mild to childhood transitions have been described previously. ${ }^{21126}$ In all 
cases the mother was the transmitting parent. This finding seems to contradict the hypothesis that maternally transmitted small mutations are more stable. One may speculate that as a rule small mutations remain relatively stable during transmission in the female germline, but if a small maternal mutation becomes unstable the risk of larger amplification, resulting in childhood or congenital disease in her offspring, is greater. ${ }^{162126}$ An alternative explanation in the present case might be that a larger expansion, with a greater propensity for further expansion in offspring, was present in III.5 and was associated with relatively mild symptoms.

The absent paternal transmission of congenital DM can be explained in this particular family by decreased fertility of males with adult onset disease. Another factor contributing to this phenomenon is the presumed selection against sperm bearing large mutations. ${ }^{2329}$

In conclusion, anticipation in this family was, once started, a relentless process occurring in all affected branches. The start of the process was asynchronous, because the transition from mild to adult type occurred in different generations, and was mainly but not exclusively influenced by the sex of the transmitting parent. The classical three step cascade is often shortened to two steps because of different reasons, the most frequent being infertility of males with adult onset disease.

We further studied DM patients and their descendants in the fourth and fifth symptomatic generations to examine the probability of transmission of the gene to the sixth generation. Gene loss in the patient group was complete, owing to infertility of the male patients with adult onset disease $(35 \%)$ and childlessness of the mentally retarded patients with childhood or congenital disease $(47 \%)$. In the nearly completely studied group of at risk asymptomatic family members, we found no carriers of a protomutation. One at risk person (V.20) was found to be carrier of a full mutation and she is the only one who may transmit the gene to the next generation. We therefore conclude that there will be complete loss of the DM gene from this family within one or two generations.

It has already been suggested by Fleischer ${ }^{4}$ that progressively increasing severity of DM leads to the elimination of the disease from a given pedigree. Systematic follow up studies to prove this hypothesis have not been performed before. On the other hand several authors presume that undetected cases may exist in the younger generations of symptomatic DM families and contribute to the maintenance of the DM gene in the population..$^{352430}$ It is important to stress that these minimal cases in younger generations of known families have not yet been observed. If our results on elimination of the gene are confirmed in other follow up studies this implies that the gene loss from known DM families is complete and that the high population frequency of DM cannot be explained by the contribution of asymptomatic cases in the younger generations of known families. A more likely source of new symptomatic DM families is the class of (CTG) ${ }^{19-30}$ alleles, with an overall frequency of $10 \%$, which probably possess predisposing properties for expansion. ${ }^{728}$ These metastable protomutations may be passed down through many generations, and in this way can spread through the population, before the accelerated cascade of anticipation starts. ${ }^{728}$ Studies on linkage disequilibrium and extensive genealogical studies, such as those in northern Quebec, support this hypothesis as they strongly suggest that one, or at most a few, ancestral mutations have been responsible for most cases of the disorder. ${ }^{31-35} \mathrm{~A}$ third possible source of new DM families are the contracted repeats in known families.

Recently Ashizawa $e t a l^{36}$ found, in a large multicentre study, that contraction of the CTG repeat, even to a normal length, occurred in approximately $6 \%$ of parent-child pairs studied and was preferentially associated with male transmission. ${ }^{36}$ Surprisingly, clinical anticipation occurred in $48 \%$ of these pairs. At present it is unclear whether these contracted repeats can be the starting point of a new anticipation cascade. ${ }^{3637}$ Follow up studies of patients with contracted repeats and of asymptomatic families with small mutations may give valuable information on the factors causing instability and hence the start of the anticipation cascade.

We wish to thank the members of the family for their kind cooperation, Dr J G Y de Jong, former neurologist in Heerlen, for providing his family data, and Mrs T Spaans for performing the genealogical studies.

1 Harper PS. Myotonic dystrophy, 2nd ed. London: W B Saunders, 1989

Koch MC, Grimm T, Harley HG, Harper PS. Genetic risks for children of women with myotonic dystrophy. $\mathrm{Am} \mathcal{F}$ Hum Genet 1991;48:1084-91

3 Harley HG, Rundle SA, MacMillan JC, et al. Size of the unstable repeat CTG sequence in relation to phenotype and parental transmission in myotonic dystrophy. $\mathrm{Am} \mathcal{J}$ Hum Genet 1993;52:1164-74.

4 Fleischer B. Über myotonische dystrophie mit katarakt: eine heriditäre, familiäre degeneration. Arch Ophthalmol 1918;96:91-133.

5 Penrose LS. The problem of anticipation in pedigrees of dystrophia myotonica. Ann Eugen 1948;14:125-32.

6 Höweler CJ, Busch HFM, Geraedts JPM, Niermeijer MF, Staal A. Anticipation in myotonic dystrophy: fact or fiction? Brain 1989;112:779-97.

7 Harper PS, Harley HG, Reardon W, Shaw DJ. Anticipation in myotonic dystrophy: new light on an old problem. $A m \mathcal{F}$ Hum Genet 1992;51:10-16.

8 Aslanidis C, Jansen G, Amemiya C, et al. Cloning of the essential myotonic dystrophy region and mapping of the putative defect. Nature 1992;355:548-51.

9 Brook JD, McCurrach ME, Harley HG, et al. Molecular basis of myotonic dystrophy: expansion of a trinucleotide (CTG) repeat at the $3^{\prime}$ end of a transcript encoding a protein kinase family member. Cell 1992;68:799-808.

10 Buxton J, Shelbourne P, Davies J, et al. Detection of an unstable fragment of DNA specific to individuals with myotonic dystrophy. Nature 1992;355:547-8.

11 Fu YH, Pizzuti A, Fenwick RG Jr, et al. An unstable triplet repeat in a gene related to myotonic muscular dystrophy. Science 1992;255:1256-8.

12 Harley HG, Brook JD, Rundle SA, et al. Expansion of an unstable DNA region and phenotypic variation in myotonic dystrophy. Nature 1992;355:545-6.

13 Jansen G, Mahadevan M, Amemiya C, et al. Characterization of the myotonic dystrophy region predicts multiple tion of the myotonic dystrophy region predicts multiple
protein isoform-encoding mRNAs. Nature Genet protein isoform

14 Mahadevan M, Tsilfidis C, Sabourin L, et al. Myotonic dystrophy mutation: an unstable CTG repeat in the $3^{\prime}$ dystrophy mutation: an unstable CTG repeat in the $3^{\prime}$
untranslated region of the gene. Science 1992;255:1253-5.

15 Harley HG, Rundle SA, Reardon W, et al. Unstable DNA sequence in myotonic dystrophy. Lancet 1992;339: sequence

16 Lavedan C, Hofmann-Radvanyi $\mathrm{H}$, Shelbourne $\mathrm{P}$, et al. Myotonic dystrophy: size- and sex-dependent dynamics of CTG meiotic instability, and somatic mosaicism. Am $\mathscr{J}$ Hum Genet 1993;52:875-83.

17 De Jong JGY. Dystrophia myotonica, paramyotonia and myotonia congenita. Thesis, University of Utrecht, 1955.

18 Brunner HG, Nillisen W, van Oost BA, et al. Presymptomatic diagnosis of myotonic dystrophy. $\mathcal{f}$ Med Genet 1992;29:780-4.

19 Shelbourne P, Davies J, Buxton J, et al. Direct diagnosis of myotonic dystrophy with a disease-specific DNA marker. $N$ Engl F Med 1993;328:471-4. 
20 Brunner HG, Smeets HJM, Nillesen W, et al. Myotonic dystrophy. Predictive value of normal results on clinical examination Brain 1991:114:2303-11.

21 Ashizawa T, Dubel JR, Dunne PW, et al. Anticipation in myotonic dystrophy. II. Complex relationships between clinical findings and structure of the GCT repeat. Neuro$\log y 1992 ; 42: 1877-83$.

22 Hunter A, Tsilfidis C, Mettler G, et al. The correlation of age of onset with CTG trinucleotide repeat amplification in myotonic dystrophy. 7 Med Genet 1992;29:774-9.

23 Brunner HG, Brüggenwirth HT, Nillisen W, et al. Influence of sex of the transmitting parent as well as of parental allele size on the CTG expansion in myotonic dystrophy. $A m \mathcal{f}$ Hum Genet 1993;53:1016-23.

24 Barceló JM, Mahadevan MS, Tsilfidis C, MacKenzie AE, Korneluk RG. Intergenerational stability of the myotonic Korneluk RG. Intergenerational stability of the myotonic
dystrophy protomutation. Hum Molec Genet 1993;2: dystrophy

25 Höweler CJ. A clinical and genetic study in myotonic dystrophy. Thesis, University of Rotterdam, 1986.

26 Redman JB, Fenwick RG Jr, Fu YH, Pizzuti A, Caskey T. Relationship between parental trinucleotide GCT repeat length and severity of myotonic dystrophy in offspring. JAMA 1993;269:1960-5.

27 Cobo AM, Baiget M, López de Munain A, Poza JJ, Emparanza JI, Johnson K. Sex-related difference in intergenerational expansion of myotonic dystrophy gene. Lance 1993;341:1159-60.

28 Wieringa B. Myotonic dystrophy reviewed: back to the future? Hum Molec Genet 1994;3:1-7.

29 Jansen G, Willems P, Coerwinkel M, et al. Gonosomal mosaicism in myotonic dystrophy patients: involvement of mitotic events in (CTG) $)_{n}$ repeat variation and selection against extreme expansion in sperm. Am $\mathcal{f}$ Hum Gene 1994;54:575-85

30 Harper PS, Harley HG, Shaw DJ. Detection of minimal mutation carriers in myotonic dystrophy. Lancet 1992;340:238-9.

31 Imbert G, Kretz C, Johnson K, Mandel JL. Origin of the expansion mutation in myotonic dystrophy. Nature Gene 1993;4:72-6.

32 Harley HG, Brook JD, Floyd J, et al. Detection of linkage disequilibrium between the myotonic dystrophy locus and a new polymorphic DNA marker. Am $\mathcal{f}$ Hum Genet 1991;49:68-75.

33 Neville CE Mahadevan MS, Barceló JM, Korneluk RG. High resolution genetic analysis suggests one ancestral predisposing haplotype for the origin of the myotonic predisposing haplotype for the origin of the myot

34 dystrophy mutation. Hum Molec Genet 1994;3:45-51. tokun BO, Ashizawa T. Dissociation of the CTG repeat expansion and the $1-\mathrm{kb}$ Alu insertion within the myotonic expansion and the 1-kb Alu insertion within the myotonic dystrophy (DM) protein kinase gene in a Niger
family. Am f Hum Genet (Suppl) 1993;53:796.

35 Matthieu J. Genealogic reconstruction of myotonic dystrophy in the Saguenay-Lac-Saint-Jean area (Quebec, Canada). Neurology 1990;40:839-42.

36 Ashizawa $\mathrm{T}$, Anvret $\mathrm{M}$, Baiget $\mathrm{M}$, et al. Characteristics of intergenerational contractions of the CTG repeat in myotonic dystrophy. Am $\mathcal{F}$ Hum Genet 1994;54:414-23.

37 Brunner HG, Jansen G, Nillesen W, et al. Reverse mutation in myotonic dystrophy. $N$ Engl f Med 1993;328:476-80. 